\title{
A Retrospective Study of Small Animal Poisoning at the Veterinary Medical Teaching Hospital from South Region of Brazil
}

\author{
Luciana Zang', Rafaela Scheer Bing', Ana Cristina Pacheco de Araujo² and Marcio Poletto Ferreira'
}

\begin{abstract}
Background: Poisoning cases are a challenge for the veterinary practitioner, since many agents can be involved. The incomplete patient history associated with advanced poisoning stage often leads to death. Since lacking information is common, it is essential to be aware of principal poisoning agents and their associated symptomatology. The aim of this study is to describe the major agents involved in small animal poisoning, the causative agent, poisoning route, time to search veterinary care, clinical signs and ancillary tests of canine and feline patients treated at the Veterinary Medical Teaching Hospital from January 2010 to June 2016.

Materials, Methods \& Results: Forty-four medical records with poisoning history were found and reviewed, but only 30 medical records had complete data to be evaluated. There were 24 dogs and 6 cats, 17 female and 13 male. Six females were spayed. Poisoning agent identification was possible in 29 cases and was food, molluscicide, cleaning product, ornamental plants, medication, rodenticide and antiparasitic drugs. Fourteen poisonings were caused by the owner and 16 were accidental. There was a higher poisoning incidence in dogs than cats. Most of the patients were young and unneutered/unspayed. Discussion: In this study there was a higher poisoning prevalence in dogs than cats, as occurred in other studies published in Europe, Belgium, France, Greece, Italy, Spain, Austria and other Brazilian regions. Most of the patients were young, which is in agreement with previous studies in which young animals were more affected. Domestic antiparasitic drugs were the most common poisoning agents (33\%), as reported in studies from France and Spain. In southern Brazil, the most common poisoning agent was medication, whereas in southeast Brazil, organophosphates were the most prevalent poisoning agent. Considering this, the geographic localisation seems to influence the poisoning agent. It is known that many owners give unprescribed medication to their pets and this also happened in this study, as $46 \%$ of the poisoning cases were caused by the owner. The most common clinical signs were gastrointestinal ( $76 \%$, emesis and anorexia) and neurological (63\%, depression). This is in agreement with another study that showed a high number of patients poisoned by medications leading to severe gastrointestinal clinical signs. Despite a history of eating spiced food, our food-poisoned patient did not show clinical signs compatible with pepper poisoning. In fact, clinical signs were more compatible with salt or onion and garlic poisoning, but there was no history to support that our patient had eaten these foods. The patient who ate fern and busy Lizzie (Impatiens walleriana) did not show clinical signs compatible with these agents but showed gastrointestinal clinical signs that could have occurred due to plant indigestion. This fact emphasises the need for more studies in this area. One dog with rodenticide poisoning presented with normal blood test results, but the blood sample was collected a few hours after exposure. This can occur after brodifacoum poisoning, which has a longer half-life than warfarin. In brodifacoum poisoning cases, clinical signs can appear days after exposure. In one dog, it was not possible to indentify the poisoning agent and this specific patient case exemplifies the challenge to diagnose the exact poisoning agent and concomitant diseases when the history is incomplete. This retrospective study shows the heterogeneity of the causative agents and the associated symptomatology, which highlights the need for further studies in this area. In this study, antiparasitic drugs were the most common poisoning agents, especially pyrethroids. Dogs were more affected than cats. Most of the patients were young and unneutered/unsprayed, indicating these characteristics could be a risk factor in this study.
\end{abstract}

Keywords: cat, dog, emergency, poisoning.

http://dx.doi.org/10.22456/1679-9216.84787

${ }^{1}$ Veterinary Medical Teaching Hospital \& ${ }^{2}$ Department of Morphology and Anatomy, School of Veterinary Medicine, Universidade Federal do Rio Grande do Sul (UFRGS), Porto Alegre, RS, Brazil. CORRESPONDENCE: L. Zang [lucianaz_23@yahoo.com.br - Tel.: +55 (51) 3308-6108]. Hospital de Clínicas Veterinárias - HCV. Av. Bento Gonçalves n. 9090. Bairro Agronomia. CEP 91540-000 Porto Alegre, RS, Brazil. 


\section{INTRODUCTION}

Poisonings are usually an emergency to a small animal practitioner. Clinical signs are usually acute and severe, so it is important that the clinician is aware of principal poisoning agents and the associated symptomatology. Usually the owners find the animals in an advanced stage of poisoning and are not capable of identifying the source or agent.

Many agents may poison small animals: plants, medications, insecticides, food, cleaning products, agrotoxics, rodenticides and molluscicides. It is known that some species are more sensitive to specific substance than others [19]. The aim of this study is to describe the major agents involved in small animal poisoning, the causative agent, poisoning route, time to search veterinary care, clinical signs and ancillary tests of canine and feline patients treated at the Veterinary Medical Teaching Hospital (Hospital de Clínicas Veterinárias), Universidade Federal do Rio Grande do Sul (UFRGS), southern Brazil from January 2010 to June 2016. We also evaluated whether there was a relationship between poisoning and the phenotypic characteristics of patients and other evaluated parameters.

\section{MATERIALS AND METHODS}

Using data from the Medical Archive and Statistics Service, all medical records with a poisoning history from January 2010 to June 2016 were reviewed. The following information was compiled from the medical records: species, breed, gender, reproductive status, age, clinical history, the causative poisoning agent, clinical signs and any altered ancillary tests. The phenotypic characteristics of the patients were compared to the poisoning agent, as an attempt to find a relationship between them. We also ranked the most common poisoning agents along with the poisoning route.

\section{RESULTS}

Forty-four medical records with a poisoning history were found and reviewed. Fourteen records were excluded because they were incomplete. Thirty medical records had complete data to be evaluated. Of those, there were 24 dogs and 6 cats (17 female and 13 male). Six females were spayed. All feline patients were mixed breed. Dog breeds represented included mixed breed dog (8), Miniature Pinscher (5), Brazilian Terrier (2), Rottweiler (2), Dachshund (1), Shih-tzu (1), Lhasa Apso (1), English Cocker Spaniel (1), Bichon Frise (1),
Labrador Retriever (1) and American Pit Bull Terrier (1). Patient age ranged from 1 month to 15 years.

Poisoning agents were: antiparasitic drugs (10), rodenticide (7), medication (6), ornamental plants (3), food (1), molluscicide (1), cleaning product (1) and unknown (1). Presumptive poisoning aetiology was considered according to the patients' clinical signs or whenever the owner saw the moment of poisoning. The probable food poisoning was suggested by the owner, who noticed her pet become ill after eating spiced food. The patient with cleaning product poisoning showed clinical signs after a house cleaning, characterising the poisoning origin. Fourteen poisonings were caused by the owner (Table 1) and sixteen were accidental (Table 2).

Seven patients presented with the following concomitant diseases when poisoning occurred: renal urolithiasis (1), peritonitis (1), hematometra (1), pyometra (1), cystitis (2), bitten wound (2) and pancreatitis (2). Tables 1 and 2 show patients' symptoms at the time of admission to the hospital, time since exposure to the poisoning agent and altered results of ancillary tests requested for each case.

\section{DISCUSSION}

In this study there was a higher poisoning prevalence in dogs than cats, as occurred in other studies published in Europe, Belgium, France, Greece, Italy, Spain [3], Austria [21] and other Brazilian regions $[9,13]$. This higher dog prevalence can be justified, since they have less selective food habits than cats [13]. In this study, as in others, symptomatology and owners' observations during the contact with a poison agent were used to diagnose the probable poison aetiology. A presumptive diagnosis is common in veterinary poisoning because specific laboratory exams are expensive $[1,13]$. One study in southern Brazil showed a positive association between low social class and poison cases [9].

Most of the patients were young [less than 2 years old (56\%)], which is in agreement with previous studies in which young animals were more affected $[1,3]$. Unneutered/unspayed animals were overrepresented (80\%); this can suggest that being unneutered could be a risk factor for poisoning. The number of female patients was higher than male (representing $56 \%$ of the cases), which is in agreement with previous studies $[1,3]$. 
L. Zang, R.S. Bing, A.C.P. Araújo \& M.P. Ferreira. 2018. A Retrospective Study of Small Animal Poisoning at the Veterinary Medical Teaching Hospital from South Region of Brazil.

Table 1. Owner related poisoning in canine and feline patient treated at HCV-UFRGS (January 2010 - June 2016), clinical signs and altered ancillary test results.

\begin{tabular}{|c|c|c|}
\hline $\begin{array}{l}\text { Drug (specie, age, time to search } \\
\text { veterinary care) }\end{array}$ & Clinical Signs & Ancillary tests altered \\
\hline $\begin{array}{c}\text { Nitrofurantoin } \\
\text { (dog, } 4 \text { months, } 2 \text { days) }\end{array}$ & Apathy, bradycardia, hypothermia & $\begin{array}{c}\text { Blood test: anisocytosis and poikilocytosis. } \\
\text { increased ALT concentration }\end{array}$ \\
\hline $\begin{array}{c}\text { Paracetamol } \\
\text { (cat, } 1 \text { year, unknown) }\end{array}$ & Eemesis, anorexia, dehydration & $\begin{array}{c}\text { Blood test: leukocytosis, neutrophilia } \\
\text { without deviation and presence of basophils, } \\
\text { hypoalbuminemia, increased ALT and AST } \\
\text { concentration }\end{array}$ \\
\hline $\begin{array}{c}\text { Paracetamol } \\
\text { (dog, } 10 \text { year, } 15 \text { days })\end{array}$ & $\begin{array}{l}\text { Eemesis, melena, anorexia, } \\
\text { tachycardia, dehydration }\end{array}$ & $\begin{array}{l}\text { Blood test: Anemia, reduced total plasmatic } \\
\text { proteins levels, leukocytosis, neutrophilia without } \\
\text { deviation, eosinophilia, monocytosis and the } \\
\text { presence of basophils. }\end{array}$ \\
\hline $\begin{array}{c}\text { Paracetamol } \\
\text { (dog, } 10 \text { year, } 6 \text { days })\end{array}$ & $\begin{array}{c}\text { Emesis, melena, dehydration, } \\
\text { hypocorate mucosa }\end{array}$ & Not done \\
\hline $\begin{array}{c}\text { Amitraz } \\
\text { (dog, } 10 \text { years, unknown) }\end{array}$ & $\begin{array}{c}\text { Apathy, mydriasis, hypocorate } \\
\text { mucosa }\end{array}$ & Blood test: anemia, eosinofilia and anisocytosis \\
\hline $\begin{array}{l}\text { Ivermectine } \\
\text { (dog, } 1 \text { month., } 24 \text { h) }\end{array}$ & $\begin{array}{l}\text { Apathy, anorexia, tremors, sialorrhea, } \\
\text { tachypnea }\end{array}$ & Not done \\
\hline $\begin{array}{c}\text { Pyrethroids } \\
\text { (cat, } 8 \text { years, } 4 \text { days) }\end{array}$ & $\begin{array}{l}\text { Apathy, anorexia, adipsia, sialorrhea, } \\
\text { hyperthermia, hypocortical mucosa }\end{array}$ & $\begin{array}{c}\text { Blood test: leukocytosis, neutrophilia without } \\
\text { deviation and icteric plasma }\end{array}$ \\
\hline $\begin{array}{c}\text { Pyrethroids } \\
(\text { dog, } 1 \text { year, }<24 \text { h) }\end{array}$ & Hyperactivity, tachycardia & Not done \\
\hline $\begin{array}{c}\text { Pyrethroids } \\
\text { (dog, 1,5 years, unknown) }\end{array}$ & Anorexia & Not done \\
\hline $\begin{array}{c}\text { Pyrethroids } \\
\text { (cat, } 4 \text { months, unknown) }\end{array}$ & Status epilepticus & Not done \\
\hline $\begin{array}{c}\text { Pyrethroids } \\
\text { (dog, 1year, } 24 \text { h) }\end{array}$ & Emesis & Not done \\
\hline
\end{tabular}

\begin{tabular}{|c|c|c|}
\hline $\begin{array}{l}\text { Pyrethroids and carbamates } \\
\text { (dog, } 4 \text { months, } 4 \text { days) }\end{array}$ & $\begin{array}{c}\text { Apathy, emesis, sialorrhea, } \\
\text { hypodipsia, anorexia, hypothermia } \\
\text { and hypoglycemia }\end{array}$ & Blood test: Leukopenia and thrombocytopenia \\
\hline $\begin{array}{l}\text { Pyrethroids and organophosphates } \\
\qquad \text { (dog, } 1 \text { year, } 4 \text { days) }\end{array}$ & $\begin{array}{l}\text { Anorexia, emesis, tachypnea, } \\
\text { hypocorate mucosa, hyperemic } \\
\text { ocular mucosa, ocular secretion, mild } \\
\text { apathy. }\end{array}$ & $\begin{array}{l}\text { Blood test: neutrophilia without deviation, } \\
\text { lymphopenia and elevated creatinine }\end{array}$ \\
\hline $\begin{array}{l}\text { Unknown Anti-Flea } \\
\text { (dog, } 1 \text { year, } 24 \text { h) }\end{array}$ & $\begin{array}{l}\text { Emesis, apathy, sialorrhea, } \\
\text { tachycardia, tremors, bite wound, } \\
\text { absent proprioception in the pelvic } \\
\text { limbs, hemorrhage of the right sclera } \\
\text { and enlarged submandibular lymph } \\
\text { node }\end{array}$ & Not done \\
\hline
\end{tabular}


Table 2. Accidental poisoning in canine and feline patient treated at HCV-UFRGS (January 2010 - June 2016), clinical signs and altered ancillary test results.

\begin{tabular}{ccc}
\hline $\begin{array}{c}\text { Drug (specie, age, time to } \\
\text { search veterinary care) }\end{array}$ & Clinical Signs & Ancillary tests altered \\
\hline $\begin{array}{c}\text { Food poisoning (cat, 1 } \\
\text { year, 24 h) }\end{array}$ & $\begin{array}{c}\text { Emesis, green diarrhea, tremors, anorexia, apathy, } \\
\text { hypothermia, dehydration, increased CRT, } \\
\text { abdominal pain, tachypnea and hypoglycemia. }\end{array}$ & $\begin{array}{c}\text { Blood test: elevated hematocrit high total } \\
\text { plasmatic proteins levels, toxic neutrophils and } \\
\text { high lactate levels }\end{array}$ \\
\hline $\begin{array}{c}\text { Capsicum sp. } \\
\text { (dog, 1year, 24 h) }\end{array}$ & $\begin{array}{c}\text { Apathy, emesis, anuria, anorexia, adipsia, } \\
\text { bradycardia, dehydration and increased CRT. }\end{array}$ & Blood test: lymphopenia and monocytosis \\
\hline $\begin{array}{c}\text { Dieffenbachia seguinte } \\
\text { (dog, 10 months, 3 days) }\end{array}$ & $\begin{array}{c}\text { Apathy, yellow emesis, yellow diarrhea, } \\
\text { hyporexia, adipsia, dehydration, hypoglycemia } \\
\text { and increased CRT }\end{array}$ & $\begin{array}{c}\text { Blood test: leukocytosis, neutrophilia without } \\
\text { deviation and presence of metamyelocytes }\end{array}$ \\
\hline
\end{tabular}

\section{Pleopeltis pleopeltifolia $\mathrm{e}$}

Impatiens walleriana

Apathy, emesis, hyporexia, diarrhea

Blood test: neutrophilia without deviation

(dog, 3 months, 2 days)

Cleaning product

(cat, 1,5 years, $24 \mathrm{~h}$ )

Metaldehyde

(dog, 10 years, $<24 \mathrm{~h}$ )

carbamazepine

(anticonvulsant)

(cat, 8 months., $<24$ h)

Apathy, lateral decubitus, emesis, mydriasis,

tachypnea, increased muscle tone in the pelvic

limbs

Eemesis, generalized tremors, tachypnea and hyperemic mucosa.
Blood test: leukopenia, lymphopenia, neutrophilia without deviation and thrombocytopenia

Blood test: leukocytosis, neutrophilia with deviation, monocytosis and thrombocytopenia

Blood test: thrombocytopenia and the presence

of basophils, High FA levels.

Urinalysis decreased urinary density, occult blood, elevated creatinine protein ratio, epithelial squamous cells

Blood test: anemia, hemolyzed

plasma, neutrophilia without deviation,
Imidocarb (dipropionate) Apathy, emesis, seizures, bloody diarrhea,

(dog, 7years, 4 days) tachypnea.

thrombocytopenia, elevated creatinine and Increased aPPT.

Abdominal US: pyometra, cystitis, liver congestion.

\begin{tabular}{cc}
\hline $\begin{array}{c}\text { Brodifacoum } \\
(\mathrm{dog}, \text { 1year, }<24 \mathrm{~h})\end{array}$ & Tachycardia \\
\hline $\begin{array}{c}\text { Warfarin } \\
(\mathrm{dog}, 3 \text { years., unknown })\end{array}$ & Apathy and diarrhea \\
\hline $\begin{array}{c}\text { Anticoagulante } \\
(\mathrm{dog}, 3 \text { years, unknown })\end{array}$ & Vomit with blood, diarrhea, hypochlorous mucosa, \\
& hypothermia, dehydration, tachycardia
\end{tabular}

unremarkable Increased aPPT
Blood test: elevated hemoglobin and hematocrit, thrombocytopenia, decreased total plasmatic protein, leukopenia, lymphopenia and the presence of toxic neutrophils. Increased PTT and aPTT.

\begin{tabular}{|c|c|c|}
\hline $\begin{array}{c}\text { Anticoagulant } \\
(\mathrm{dog}, 10 \text { years, unknown })\end{array}$ & $\begin{array}{c}\text { Tachycardia, hypocorate mucosa, increased CRT, } \\
\text { dehydration. Spontaneous bleeding. }\end{array}$ & Increased PTT and aPTT. \\
\hline $\begin{array}{c}\text { Anticoagulant } \\
\text { (dog, } 14 \text { years, } 7 \text { days })\end{array}$ & $\begin{array}{l}\text { Polydipsia, hematuria, dehydration, liquid } \\
\text { diarrhea, bleeding in the oral mucosa and vaginal } \\
\text { mucosanguinolenta secretion. }\end{array}$ & $\begin{array}{l}\text { Blood test: leukocytosis, neutrophilia } \\
\text { without deviation, eosinophilia, monocytosis, } \\
\text { lymphocytosis, thrombocytopenia and the } \\
\text { presence of toxic neutrophils and activated } \\
\text { monocytes, elevated ALT and AF, decreased } \\
\text { creatinine and urea, increased PPT and aPTT. } \\
\text { Abnominal US: renal lithiasis }\end{array}$ \\
\hline
\end{tabular}

(continues...) 


\begin{tabular}{|c|c|c|}
\hline $\begin{array}{c}\text { Anticoagulant } \\
\text { (dog, } 15 \text { years, unknown) }\end{array}$ & $\begin{array}{l}\text { Vulvar bleeding, emesis with blood, anuria, } \\
\text { anorexia, epistaxis, abdominal algia, tachypnea, } \\
\text { hyperemic mucosa, muffled heart auscultation. }\end{array}$ & $\begin{array}{l}\text { Blood test: leukocytosis, neutrophilia without } \\
\text { deviation, monocytosis, lymphopenia, } \\
\text { thrombocytopenia with the presence of } \\
\text { macroplots. } \\
\text { Abdominal US: pancreatitis, hepatomegaly, renal } \\
\text { litter, hemometra / estrous period, peritonitis, } \\
\text { free fluid, cystic ovary. } \\
\text { Urinalisys: bilirubinuria, proteinuria, squamous } \\
\text { and transitional cells. Necropsy: Hemorrhagic } \\
\text { syndrome of unknown cause. }\end{array}$ \\
\hline $\begin{array}{c}\text { Anticoagulant } \\
\text { (dog, } 3 \text { years, unknown) }\end{array}$ & $\begin{array}{c}\text { Seizure, tachycardia, hyperemic mucosa, } \\
\text { increased CRT, tachypnea }\end{array}$ & $\begin{array}{c}\text { Blood test: lymphopenia, elevated ALT and } \\
\text { creatinine, hypoalbuminemia and Increased PTT } \\
\text { and aPTT. } \\
\text { Abdominal US: pancreatitis }\end{array}$ \\
\hline $\begin{array}{c}\text { Unknown } \\
(\mathrm{dog}, 4 \text { years, unknown) }\end{array}$ & $\begin{array}{c}\text { Sialorrhea, seizure, emesis, generalized tremors, } \\
\text { myoclonus, dehydration, tachycardia, tetany, } \\
\text { urinary incontinence. }\end{array}$ & Not done \\
\hline
\end{tabular}

AST: Aspartate transaminase; ALT: Alanine transaminase; FA: alkaline phosphatase; aPTT: activated partial thromboplastin time; Abdominal US: Abdominal ultrasound; PTT: Partial thromboplastin time.

Domestic antiparasitic drugs were the most common poisoning agents (33\%), as reported in studies from France and Spain [3]. On the contrary, in Belgium and Greece [3], most poisonings were due to carbamate. In southern Brazil, the most common poisoning agent was medication, whereas in southeast Brazil, organophosphates were the most prevalent poisoning agent $[9,13]$. Considering this, the geographic localization seems to influence the poisoning agent [1].

It is known that many owners give unprescribed medication to their pets [13] and this also happened in this study, as $46 \%$ of the poisoning cases were caused by the owner. Owner involvement in poisoning cases was higher in this study than previously reported [9].

The most common clinical signs were gastrointestinal (76\%, emesis and anorexia) and neurological (63\%, depression). This is in agreement with another study that showed a high number of patients poisoned by medications leading to severe gastrointestinal clinical signs [10]. Our findings may be explained by the prevalence of poisoning route $(63 \%$ oral and $30 \%$ cutaneous). This poisoning route frequency is in agreement with the literature [3]. Blood exams are usually non-specific but are important to monitor a patient's state [16]. Considering blood test results, the most commonly affected test was the complete haemogram (i.e., leukocytosis), which can be a response to stress [16].
Despite a history of eating spiced food, our food-poisoned patient did not show clinical signs compatible with pepper poisoning. In fact, clinical signs were more compatible with salt or onion and garlic poisoning, (i.e., haematological, gastrointestinal and respiratory clinical signs), but there was no history to support that our patient had eaten these foods. In salt poisoning, clinical signs can occur in many organic systems: gastrointestinal, neurologic, respiratory, cardiac, renal, endocrine and muscular [14]. In pepper poisoning, capsaicin is the active component in clinical signs [5]. Capsaicin is an antagonist of the sensitive neurons polymodal channels that are found in epithelial cells and smooth vascular muscle [9]. When ingested at high doses, capsaicin can cause systemic hypotension, bradycardia, sialorrhea, decreased gastric secretions, vasospasms and apnea $[7,12,18,19]$. This may suggest that food poisoning can be related to food ingredients other than pepper. Another patient, poisoned by an ornamental pepper plant presented with pepper poisoning clinical signs $[5,7,12,18,19]$. The toxic dose of capsaicin varies among species and between contamination routes, which may explain the different clinical manifestations among patients $[6,8,15]$.

The patient who ate fern and busy Lizzie (Impatiens walleriana) did not show clinical signs compatible with these agents but showed gastrointesti- 
nal clinical signs that could have occurred due to plant indigestion. This fact emphasises the need for more studies in this area $[2,17]$. There is no published data on ornamental fern poisoning (Pleopeltis pleopeltifolia), although eagle fern (Pteridium aquilinun) can poison farm animals. Eagle fern poisoned animals show acute signs of anemia, medullary aplasia, spontaneous haemorrhages, hyperthermia and petechiae $[2,12,16]$. Impatiens walleriana is studied because of its antibiotic properties but does not seem to have a toxic component [11]. Considering this, it is unlikely that the patient's clinical signs were caused by a toxin found in this plant.

One dog with rodenticide poisoning presented with normal blood test results, but the blood sample was collected a few hours after exposure. This can occur after brodifacoum poisoning, which has a longer half-life than warfarin (120 days and $14 \mathrm{~h}$, respectively). In brodifacoum poisoning cases, clinical signs can appear days after exposure [16]. This can explain differences in time to clinical poisoning manifestation that occurred in our patients. [16,20].

In one dog, it was not possible to indentify the poisoning agent. It presented with clinical signs compatible with high doses of carbamates, organophosphates, organochlorines, pyrethroids, strychnine or metaldehyde
[16]. The other two dogs that lived at the same house died in less than $6 \mathrm{~h}$. All of these agents can cause the clinical signs observed in our patient $[4,14,16]$. This specific patient case exemplifies the challenge to diagnose the exact poisoning agent and concomitant diseases when the history is incomplete. A previous study also demonstrated the difficulty in determining the poisoning agent (or even if there was a poisoning) of 101 suspected poisoning cases, in 34 cases the poisoning agent was either considered unknown $(56 \%)$ or had a final diagnosis of non-poisoned (44\%) [13].

\section{CONCLUSION}

This retrospective study shows the heterogeneity of the causative agents and the associated symptomatology, which highlights the need for further studies in this area. In this study, antiparasitic drugs were the most common poisoning agents, especially pyrethroids. Dogs were more affected than cats. Most of the patients were young and unneutered/unsprayed, indicating these characteristics could be a risk factor in this study.

Declaration of interest. The authors report no conflicts of interest. The authors alone are responsible for the content and writing of the paper.

\section{REFERENCES}

1 Abreu B.A. \& Silva D.A. 2014. Drogas relacionadas a casos de intoxicações em cães. Acta Biomedica Brasiliensia. 5: $71-78$.

2 Anjo B.L., Irigoyen L.F., Piazer J.V., Brum J.S., Fighera R.A. \& Barros C.S. 2009. Intoxicação experimental aguda por samambaia (Pteridium aquilinum) em bovinos. Pesquisa Veterinária Brasileira. 29: 753-766.

3 Berny P., Caloni F., Croubels S., Sachana M., Vandenbroucke V., Davanzo F. \& Guitart R. 2010. Animal poisoning in Europe. Part 2: companion animals. Veterinary Journal. 183: 255-259.

4 Ceccherini G., Perondi F., Lippi I., Guidi G. \& Marchetti V. 2015. Intravenous lipid emulsion and dexmedetomidine for treatment of feline permethrin intoxication: a report from 4 cases. Open Veterinary Journal. 5: 113-121.

5 Chanda S., Mould A., Esmail A. \& Bley K. 2005. Toxicity studies with pure trans-capsaicin delivered to dogs via intravenous administration. Regulatory Toxicology and Pharmacology. 43: 66-75.

6 Chanda S., Sharper V., Hoberman A. \& Bley K. 2006. Developmental toxicity study of pure trans-capsaicin in rats and rabbits. International Journal of Toxicology. 25: 205-217.

7 Coleridge H.M., Coleridge J.C. \& Kidd C. 1964. Role of the pulmonary arterial baroreceptors in the effects produced by capsaicin in the dog. Journal of Physiology. 170: 272-285.

8 Glinsukon T., Stimunnaithum V., Toskulkao C., Buranawuti T. \& Tangkrisanavinont V. 1980. Acute toxicity of capsaicin in several animal species. Toxicon. 18: 215-220.

9 Hanse D.T. 2006. Prevalência de intoxicação de cães e gatos em Curitiba. 72f. Curitiba, PR. Dissertação (Mestrado em Ciências Veterinárias) - Programa de Pós-graduação em Ciências Veterinárias, Universidade Federal do Paraná.

10 Hiet S.C., Owen M.K., Li W., Chen X., Riley A., Noblet J., Flores S., Sturek M., Tune J.D. \& Obulhov A.G. 2014. Mechanisms underlying capsaicin effects in canine coronary artery: implications for coronary spasm. Cardiovascular Research. 103: 607-618. 
11 Lopes R.K., Ritterm R.M. \& Rates S.M. 2009. Revisão das atividades biológicas e toxicidade das plantas ornamentais mais utilizadas no Rio Grande do Sul, Brasil. Revista Brasileira de Biociências. 7: 305-315.

12 Martins D.B., Martinuzzi P.A., Sampaio A.B. \& Viana A.N. 2013. Plantas tóxicas: uma visão dos proprietários de pequenos animais. Arquivo de Ciências Veterinárias e Zoologia da UNIPAR. 16: 11-17.

13 Medeiros R.J., Monteiro F.O., Silva G.C. \& Nascimento Júnior A. 2009. Casos de intoxicações exógenas em cães e gatos atendidos na Faculdade de Veterinária da Universidade Federal Fluminense durante o período de 2002 a 2008. Ciência Rural. 39: 2105-2110.

14 Osweiler G.D., Hovda L.R., Brutlag A.G. \& Lee J.A. 2011. Salt. In: Blackwell's five-minute veterinary consult clinical companion: small animal toxicology. Ames: Blackwell Publishing Ltd., pp.461-469.

15 Saito A. \& Yamato M. 1996. Acute oral toxicity of capsaicin in mice and rats. The Journal of Toxicological Sciences. 21: $195-200$.

16 Manoel C.S. 2008. Como lidar com os principais agentes intoxicantes na rotina de atendimento emergencial de pequenos animais. In: Santos M.M. \& Fragata F.S. (Eds). Emergência e terapia intensiva veterinária em pequenos animais: bases para o atendimento hospitalar. São Paulo: Roca, pp.492-588.

17 Santos P.C.G., Bruscki F.J., Roder P.R., Vivan R.C. \& Petrillo V.H.M. 2003. Intoxicação por samambaia. Revista Científica Eletrônica de Medicina Veterinária. 1: 1-3.

18 Toda N., Usui H., Nishino N. \& Fujiwara M. 1972. Cardiovascular effects of capsaicin in dogs and rabbits. The Journal of Pharmacology and Experimental Therapeutics. 181: 512-521.

19 Toh C.C., Lee T.S. \& Kiang A.K. 1955. The pharmacological actions of capsaicin and analogues. British Journal of Pharmacology. 10: 175-182.

20 Valchev I., Binev R., Yordanova V. \& Nikolov Y. 2008. Anticoagulant rodenticide intoxication in animals - A review. Turkish Journal of Veterinary and Animal Sciences. 32: 237-243.

21 Wang Y., Kruzik P., Helsberg A., Helsberg I. \& Rausch W.D. 2007. Pesticide poisoning in domestic animals and livestock in Austria: a 6 years retrospective study. Forensic Science International. 169: 157-160. 